\title{
Governance and attractiveness of FDI: the case of Southern and Eastern Mediterranean countries
}

\author{
Akram Belhadj Mohamed ${ }^{1 *}$, Mgadmi Nidhal $^{2}$ \\ ${ }^{1}$ Faculty of Economics and Management of Mahdia, Tunisia \\ ${ }^{2}$ Faculty of Law, Economics and Management of Jendouba, Tunisia \\ *Corresponding Author: Akram Belhadj Mohamed: Akram781@gmail.com
}

OPEN ACCESS

\section{Citation Akram Belhadj \\ Mohamed, Mgadmi Nidhal (2017) Governance and attractiveness of FDI: the case of Southern and Eastern Mediterranean countriesOpen Science Journal 2(3).}

Received: $5^{\text {th }}$ July 2017

Accepted: $9^{\text {th }}$ August 2017

Published: $23^{\text {rd }}$ August 2017

Copyright:@ 2016 This is an open access article under the terms of the Creative Commons Attribution License, which permits unrestricted use, distribution, and reproduction in any medium, provided the original author and source are credited.

Funding: The author(s) received no specific funding for this work.

Competing Interests: The author have declared that no competing interests exists.

\begin{abstract}
This article empirically examines the role of governance in attracting FDI for a sample of ten Southern and Eastern Mediterranean countries over a 15-year period. We have approximated the attractiveness of FDI by governance through an endogenous variable called FDI in relation to GDP. The quality of these variables was tested by the positioning, dispersion and shape indicators and verified the normality of these variables by the Jarque-Berra test and the quality of linear adjustment of each variable with respect to its mean. The empirical validation of the impact of good governance in the attraction of FDI was carried out using the static Panel technique and based on the assumption of the absence of a stationarity problem for the explanatory variables of our model . Homogeneityheterogeneity tests were used to specify the reference model and model the role of governance in the attraction of FDI by a panel with individual effects. The estimation of this model by the Within and GLS procedures yielded significant results.
\end{abstract}

Keywords: Governance, Attraction of FDI, Static Panel. 


\section{Introduction}

There is widespread debate amongst researchers and governments around corporate governance. In the United Kingdom and the United States, the focus is on weaknesses in the market system in terms of the effectiveness of corporate governance. In continental Europe, there is concern that current corporate governance systems are hampering innovation and growth. In Eastern Europe, privatization leads to questions about how private companies should be governed. China is experiencing some forms of corporate governance combining features of the market system with a public ownership regime. In spite of all these debates, the observations concerning the effects of the different systems of corporate governance remain fragmentary. In the area of corporate governance, the facts were swept aside by the judgments.

This article is structured around both parts. In the first part, we will synthesize the main empirical work that has addressed the role of governance in attracting FDI. In the second part, we will try to verify this role from an econometric application on a sample of southern and eastern Mediterranean countries.

\section{Review of Literature}

Several studies have attempted to test the impact of governance mechanisms and the choice of financial structure on firm performance (Tong and Tong 2002, Gompers, Ishii and Metrick 2003 and Cremers and Nair 2005, Allen N. Berger, Emilia Bonaccorsi Di Patti 2006 and Lerong He 2008). The review of these studies shows a wide variety of variables used to measure the corporate governance structure. Some work focuses on the right of shareholders to vote (Bethel and Gillian 2002 and Kunz and Angel 1996). Other work is based on the firm's ownership structure to test the impact of governance mechanisms on the firm's value: Hiraki et al (2003), Sung (2003), Chen (2001) and Kumar (2004)) Respectively in Japan, South Korea, China and India.

Recently, the idea of building a governance index that synthesizes all control mechanisms has prompted empirical research to test the effectiveness of a governance structure in aligning the interests of managers Shareholders (for example, Hermalin and Weisbach 2003). The work in this framework focuses on the governance-performance relationship (Gompers, Ishii and Metrick (2003) and Gillan, Hartzell and Starks (2003)). Some empirical results show that a better governance structure results in better performance (Bebchuck and Cohen 2004, Cohen and Ferrel 2004), other research fails to establish a meaningful relationship between the governance structure and its performance. Moreover, research that attempted to establish a relationship between the governance index and the capital structure is very rare (Friedman, Johnson and Mitton 2003, Jiraporn et al., 2004 and Litov 2005). The review of this work shows that some research uses the governance index to measure the level of leadership rooted (Litov 2005) and the level of protection of shareholders' rights (Jiraporn 2004). Others aim, through the construction of a governance index, to test the relevance of the hypothesis that the use of debt and the establishment of a good governance 
structure are two substitutable control mechanisms (Burak et al 2005). Similarly, other studies use the governance index as constructed by Gompers et al. (2003) to test the impact of quality of governance on the cost of capital (Klock, Mansi, and Maxwell 2004).

The empirical studies of Jiraporn et al. (2014) and Litov (2015) have sought to test whether "well-governed" firms that are characterized by low agency costs and low levels of asymmetry of information, Make more use of debt to finance their investment opportunities. To make themselves the authors call on the index of governance conceived by Gompers, Ishii and Metrick (2003). These authors classify 24 governance arrangements into five categories: Tactics for Delaying Hostile Bidders, Voting, Protection, Takeover and State Laws . The governance index is constructed as follows: for each company, the authors sum up "one" for each provision that delineates the shareholder's rights (which increases the discretion of the manager). Therefore, the level of index G indicates how low the shareholder's rights are. A high value of index $G$ implies that it is difficult for stakeholders, including external investors, to dismiss a manager or replace the board of directors.

Based on the methodology adopted by Gompers, Ishii and Metrick (2003), Jiraporn et al (2014) examined the impact of the governance structure on the level of total indebtedness. He argued that the size of agency costs between executives and shareholders is likely to be inversely related to the effectiveness of control put in place by shareholders. At this level, the capital structure is linked to agency costs and agency costs, in turn, are associated with shareholder rights. The authors assume that financial choices are influenced by the level of protection of shareholder rights within the firm.

In a first step, Jiraporn et al (2014) proceeded by a single-varied analysis and subdivides its sample into two groups according to the level of the governance index. Companies whose index value is greater than or equal to 14 are placed in the "Dictatorship Portfolio" group, while those with a government index of less than or equal to 5 are placed in the "democracy" group (Democracy Portfolio). Jiraporn (2014) found that firms of the "dictatorship" type are more indebted than those of the "democracy" type. Indeed, the average debt ratio for the "dictatorship" group is $49 \%$ whereas it is only $44.36 \%$ for the group of firms qualified as "democracy". These results confirm the suggestion that firms with low rights for their shareholders use debt more than firms with good protection of their rights. Jiraporn et al (2014) suggested that its findings support the predictions of agency theory insofar as debt is used as a disciplinary means within firms. In a second step, it adopted a multi-varied regression to test the impact of shareholders' rights on the level of indebtedness. To control the possibility of nonlinearity of the relation, the author included a quadratic relation. The coefficient of the governance index is positive and highly significant, indicating an inverse relationship between the use of debt and the strength of shareholder rights.

In the model that includes the possibility of a quadratic relationship between the level of debt and shareholder rights, the coefficient of the high squared governance index is statistically insignificant, thus rejecting a parabolic relationship. Recently, Litov et al (2015) carried out a study similar to that of Jiraporn et al (2014), taking into account the American context for the period 1990 to 2013. They used the index retained by Gompers et al (2003) to measure 
the level of leadership rooted. The higher the value of the $G$ index means the higher the level of rooting of the leader.

Jiraporn et al (2014) classified the total sample into five quartiles according to the level of leadership rooted. Results show that the ratio of debt to book value and market value increases with the level of rooting (the debt ratio rises from 0.485 when $G$ is less than 6 to wait 0.571 when $G$ is greater than 13 ). These results contradict the suggestion that ingrained leaders prefer a low level of indebtedness. The theoretical explanation of the positive relationship between the level of rooting and the debt decision is based on the endogenous choice of the level of risk taken by managers in an investment policy, depending on the effectiveness of The governance structure in place. In a well-governed environment (WellMonitored), supervised executives agree to undertake risky projects because it is easy to determine the quality of managers (poor quality vs. good quality). Indeed, the effectiveness of governance mechanisms tends to reduce the risk aversion of the manager justified mainly by their human capital and provided incentives to increase target debt levels (Target Ratio).

To test the explanatory power of the governance structure on the change in the debt ratio, Jiraporn et al (2014) adopted a model similar to that established by Frank and Goyal (2003), which aims to test the relevance of the theory Hierarchy of funding. The latter is tested according to the chosen quartiles, which break down the firms according to the degree of rooting of their managers. The author's findings suggest that the Pecking Order theory works better in firms characterized by a high level of roots on the part of their leaders. Indeed, the order of financing followed by these firms is as follows: self-financing, debt and equity as a last resort. Concerning the dynamic relationship between the root level and the debt, the study by Litov et al (2015) showed that an increase in the root index $\mathrm{G}$ (such as the insertion of a new disposition Anti-takeover bid) is associated with an average increase of $3.16 \%$ in the debt-to-value ratio and $2.25 \%$ in the debt-to-market ratio. At the conclusion of his study, Litov et al (2015, p. 12) emphasized an important empirical relationship, namely the causality between the governance structure and debt:

The work of Kale et al (2015) aimed to test the relationship between governance structure and debt as two substitutable control mechanisms for a sample of 2408 US firms. To test the duality of this relation, the authors retained two simultaneous equations. According to the first, these authors sought to examine the relevance of the governance structure as a deterministic factor in the level of indebtedness. The results show that the governance index negatively affects debt (the coefficients vary between -0.0523 and -0.4854 and are significant at the $1 \%$ threshold). Through the second equation, these authors tend to examine the deterministic role of debt for the establishment of a governance structure.

The results show that indebtedness negatively affects the governance index (coefficients vary between - 0.0740 and - 0.2013). These results suggest, therefore, that debt and the governance structure are two substitutable control mechanisms. By adopting a dynamic vision, Kale et al (2015) argued that managers reduce their debt levels when faced with an exogenous increase in governance mechanisms . To test this suggestion empirically, the authors carried out a comparative study of the debt levels before and after the imposition of the Sarbanes-Oxley Act in 2002 and the rigorous governance mechanisms 
implemented by NASDAQ and NYSE in 2003. The results show that the total debt ratios measured at market value and at book value decline between the periods 1999,2000 and 2001 and 2003. For example, the average debt-to-equity ratio increased from 0,228 in 1999 To 0.195 in 2003, ie an approximate decrease of $14.5 \%$. Friedman, Johnson and Mitton (2003) estimated the relationship between corporate governance and debt level for a sample of 447 Asian, European and Latin American firms. For Asian firms, they found that low corporate governance is associated with high levels of debt. Despite this constructive research, attention to exploring organizational finance to enrich the explanation of the determinants of firms' financing choices remains limited.

In particular, the vein of work on the determinants of the capital structure, although fruitful, neglects the explanatory power of the ownership structure. Pablo de Andrés et al (2006) in this context, their paper have developed responses to the relationship between bank performance and effective supervision of bank agency managers. They considered the question of whether banks with less efficient boards show results that are different from those banks that can direct and advise their managers more effectively, because such differences could be due to weaknesses in different control mechanisms.

\section{Empirical validation and results}

In this article, we will analyze the effect of good governance in attracting foreign direct investment (FDI), ie we demonstrate the contribution of good governance in the creation of a Favorable climate for FDI. To do so, we will verify this contribution from a sample of the ten SEMC countries during a study period from 2000 to 2014. Our sample contains the following countries: Algeria, Egypt, Israel , Jordan, Lebanon, Libya, Morocco, Syria, Tunisia, Turkey.

We will use several endogenous and explanatory variables in order to understand the importance of governance on the increase of direct investment abroad. To do this, we approximate the movement of attraction of FDI by governance by the variable explained FDI-GDP. This variable is expressed as the flow of FDI relative to gross domestic product (GDP).

These FDIs represent the net inflows of investments to acquire a sustainable investment in an enterprise operating in an economy other than investment. This variable corresponds to the sum of own funds, reinvestment of profits, other longterm capital and short-term capital. This variable expresses the net inflows of new investment flows into the reporting economy by foreign investors and is divided by GDP. Our endogenous variable is released from the World Bank. The explanatory variables for the attractiveness of FDI are subdivided into variables of governance and macroeconomic variables.

The governance variables are: Infrastructure, Citizen Voice and Responsibility, Political Stability and Absence of Violence, Government Effectiveness, Rule of Law, Regulatory Quality and Fighting Corruption. The macroeconomic variable represents the per capita gross domestic product in constant dollars for the 2010 base year, which measures purchasing power parity and human capital. 
The infrastructure (Infr) is approximated by the number of telephone lines per 100 inhabitants, it is a variable that represents the infrastructure in the host country. We obtained this variable from the World Bank and this corresponds to the industrial factor which has a crucial influence in the increase of FDI in a country.

Voice of citizenship and responsibility (VOA) is expressed by the perception of the capacity of citizens of a country to participate in the selection of their leaders, as well as freedom of expression, freedom of association and free media. This VOA has an institutional power and in this work we are based on the works of Kaufman et al. (1999) and Transparency International, to obtain the data base for the period 2000-2014.

Political Stability and Absence of Violence (SPAV) is the probability that the government will be destabilized or overthrown by unconstitutional or violent means. This stability is an institutional variable and is obtained from the work of Kaufman et al. (1999).

Public Service Effectiveness (PPE) is measured the quality of public services, the quality of the public service and the degree of its independence from political pressures, the quality of policy formulation and the implementation and credibility of the public service. Government's commitment to these policies. This $\mathrm{CPE}$ is an institutional variable emerging from the work of Kaufman et al. (1999).

The perception of the extent to which agents trust and respect the rules of the company and in particular the quality of the performance of contracts, property rights, the police and the courts as well as The likelihood of crime and violence. This ED is estimated from Kaufman et al. (1999) and represents an institutional factor.

Regulatory Quality (RQ) is the government's ability to formulate and enforce policies and regulations that allow and promote private sector development. This quality is obtained from Kaufman et al. (1999). Fight against corruption is approximated by the capacity of the government to formulate and implement policies and regulations that enable and promote the development of the private sector.

Human capital (HC) is measured by the enrollment rate in secondary education. This capital is the commercial factor of attractiveness of FDI. Our database contains two dimensions: a temporal dimension spanning 15 years and an individual dimension of the ten SEMC countries. For this purpose, we will use advanced econometric techniques to estimate these individual-temporal data.

We will use position, dispersion and form indicators to analyze our data base for our sample of SEMC countries which includes: Algeria, Egypt, Israel, Jordan, Lebanon, Libya, Morocco, Syria, Tunisia, Turkey during a study period from 2000 to 2014. Our database contains nine variables: FDI-GDP, VOA, STAB, GOV, QUAL, STATE, CORR, INF, CH, GDP. From the position indicators (see table 1 in Appendices), we can see that the averages are negative for the explanatory variables of political stability, citizen voice, governance, quality of regulation, state and law and corruption. On the other hand, these averages are positive for the endogenous variable (FDI-GDP) and gross domestic product, infrastructure and human capital.

The median divides the population of each variable into two equal parts. Also, we note that the number of observations equal to 150 and the cross-section 
is equal to 10 . We will study the estimation quality and the adjustment of each component of our database based on absolute and relative dispersion indicators. For this purpose, Table 2 (see Appendices) corresponds to the dispersion criteria for these variables. We find from the dispersion indicators that the standard deviations are very low for variables VOA, Stability, Governance, Quality and regulation, State and law and corruption. Hence, this is a good fit for these variables.

On the other hand, the standard deviations are high for the endogenous variable and the rest of the explanatory variables and the linear adjustment of these variables is very poor. The precision indicator is bad for the endogenous variable because the variance of this variable is very high.

On the other hand, the risks for the variables where the very low standard deviations are very minimal. We will study the normality of these explanatory variables and the contribution of FDI to economic growth for the ten SEMC (Southern and Eastern Mediterranean) countries. countries through the JarqueBerra statistics. Table 3 (see Appendices) summarizes the shape indicators for these variables.

Referring to this table we can see that the variables VOA, Qual, State and $\mathrm{CH}$ follow normal laws since Jarque-Bera statistics are less than the tabulated value of Chi-two at two degrees of freedom. On the other hand, the endogenous variable, ie the contribution of FDI to economic growth for the sample of SEMC countries during our study period, does not follow the normal law because the Jarque-Bera statistic is significant At the $1 \%$ risk threshold.

The nonlinearity of this variable is explained by the asymmetry of the information for the FDI relative to the gross domestic product and the nonflattening. Also, the fight against corruption, infrastructure, GDP and governance do not follow the normal law because their Jarque-Bera statistics are higher than the critical value of the Chi-two law with two degrees of freedom. Despite this, the governance variable follows the normal law only within a risk threshold of $5 \%$ and $1 \%$. We will try to estimate a static relationship that describes the contribution of direct investment abroad to GDP in terms of the various explanatory variables: Infrastructure (Inf), Voice of Citizenship and Responsibility (VOA), Political Stability and Absence (QUAL), Rule of law (State), Quality of regulation (Gov) and Fight against corruption (CORR). The macroeconomic variable represents the per capita gross domestic product (GDP) in constant dollars for the 2010 base year that measures purchasing power parity.

We will estimate our reference model during a study period from 2000 to 2014 for a sample of ten countries: Algeria, Egypt, Israel, Jordan, Lebanon, Libya, Morocco, Syria, Tunisia, Turkey. Our basic model can be written in the following form:

$$
\begin{aligned}
& F D I G D P_{i t}=\alpha_{i}+\beta_{i} \mathrm{VOA}_{\mathrm{it}}+\chi_{i} \mathrm{STAB}_{i t}+\delta_{i} \mathrm{GOV}_{i t}+\phi_{i} \mathrm{QUAL}_{i t}+\gamma_{i} \mathrm{STATE}_{i t}+\lambda_{i} \mathrm{CORR}_{i t}+\varphi_{i} \mathrm{INF}_{i t} \\
& \quad+\eta_{\mathrm{i}} L G D P_{i t}+\tau_{i} L C H_{i t}+\varepsilon_{i t}
\end{aligned}
$$

The innovations $\varepsilon_{i t}$ are assumed to be iid of zero mean and of variance equal to $\sigma_{\varepsilon}^{2}, \mathrm{i} \in[1, \mathrm{~N}]$ 
Table 4 (see Appendices) will present the homogeneity tests for our basic model. We note that all the coefficients are ideal for the ten SEMC countries, although the constants are different for these countries.

For this purpose, we specify the contribution of FDI to GDP by a panel with individual effects. We will use the Within and GLS techniques to estimate this contribution. Table 5 (see Appendices) summarizes these two estimation procedures in the observation of static relations. They describe the linear equation that links FDI to GDP in terms of the explanatory variables of governance and macroeconomics.

The estimation of the static relationship that describes the contribution of FDI to GDP for the sample of SEMC countries yields expected and significant results. But, corruption has a positive and insignificant impact on the Within or LSDV method. On the other hand, this corruption has a negative and significant effect by the GLS method. The law and the state play a positive and not significant role in the increase of the FDI volumes for the Within technique but significant by the GLS procedure. Gross domestic product has a positive and significant influence on the two appropriate technologies. Political stability has a negative and insignificant effect on FDI volumes. We will use the Hausman arbitration test (1978) to identify the nature of the individual effects. Table 6 (see Appendices) corresponds to the Hausman test (1978) for the contribution of FDI to GDP for the SEMC area during a study period from 2000 to 2014.

Hausman's (1978) statistic is greater than the tabulated chi-square value at nine degrees of freedom. Hence, the individual effects are fixed and we choose the In technique to estimate the static relationship that links the contribution of FDI to GDP as a function of the explanatory variables.

\section{Conclusion}

In this paper, we examined the role of governance in attracting FDI. For this, we have empirically analyzed this effect from a sample of the ten countries over a period of 15 years. We approximated the movement of FDI attractions by governance by an endogenous variable called FDI versus GDP. This variable corresponds to the contribution of FDI to economic growth. Our database is extracted from the World Bank for nine variables: IDE-GDP, VOA, STAB, GOV, QUAL, STATE, CORR, INF, CH, GDP.

These variables group into three groups: An endogenous FDI-GDP variable, governance variables that are; (VOL), Political Stability and Absence of Violence (STAB), Government Effectiveness (GOV), Rule of Law (STATUS), Quality of Regulation and Fighting Corruption (CORR) ) And the macroeconomic variables that are; Gross domestic product (GDP) and human capital (HC). We have studied the quality of these variables by the position, dispersion and shape indicators. We verified the normality of these variables by the Jarque-Berra test and we detected the quality of linear adjustment of each variable with respect to its mean.

The empirical validation of the impact of good governance on the attraction of FDI and economic growth is validated from a sample of the 10 countries over 15 years. For this we used the Static Panel technique and based on the 
assumption of the absence of a stationarity problem for the explanatory variables of our basic model.

We have referred to the homogeneity-heterogeneity tests to specify this reference model and we model the role of governance in the attraction of FDI by a panel with individual effects. We have estimated this model by the Within and GLS procedures. These estimation procedures yield expected and significant results. We have arbitrated between these two procedures estimates by the Hausman test (1978). We have identified the nature of individual effects by fixed special characters that are invariant over time.

\section{References}

Berger, S.E and Banaccorsi, di P. (2006). Capital Structure and firm performance: A new approach to testing agency theory and an application to the bank industry, Journal of Banking and Finance, no 30, pp. 1065-1102.

Burak and al. (2005, p.9). The Impact of Industry 4.0 on the Supply Chain, Innovations and Strategies for Logistics and Supply Chains Technologies, Business Models and Risk Management, Proceedings of the Hamburg International Conference of Logistics.

Bebchuk, L.A and Cohen A. (2004). The costs of entrenched boards, Working paper, John M. Olin Center for Law, Economics and Business, Harvard Law School.

Bebchuk L.C and Ferrell A. (2004). What matters in corporate governance?, Working Paper, de Harvard Law School.

Bethel, J.E and Gillian, S.L. (2002). The Impact of the Institutional and Regulatory Environment on Shareholder Voting, Financial Management, Vol. 31, pp. 29-54.

Cremers, K J M and Nair V B. (2005). Governance mechanisms and Equity Prices, Journal of Finance, no 60, pp. 2859-2894.

Chen J.C. (2001). Ownership structure as corporate governance mechanism: evidence from Chinese listed companies, Economics of Planning, Vol. 34, pp. 53-72

Frank M.Z and Goyal V.K. (2003). Testing the Pecking Order Theory of Capital Structure, Journal of Financial Economics, No 67, pp. 217-248.

Friedman, E, Simon J and Todd M. (2003). Propping And Tunneling, Journal of Comparative Economics, Vol. 31, pp. 732-750

Georgia K.J., Ryan Jr, H.E and Wang L. (2015). Debt as a bonding mechanism: Evidence from the relations between employee productivity, capital structure, and outside employment opportunities, Working Paper, Georgia State University.

Gompers, P.A, Ishii, J.L and Metrick, A. (2003). Corporate Governance and Equity Prices, Quarterly Journal of Economics, Vol. 118, no 1, pp. 107-155.

Hermalin B.E and Michael S.W. (2003). Boards of Directors as an Endogenously Determined Institution: A Survey of the Economic Literature, Federal Reserve Bank of New York, Economic Policy Review, no 9(1), pp. 7-26.

Hiraki T, Inoue H, Ito A, Kuroki F and Masuda H. (2003). Corporate governance and firm value in Japan: Evidence from 1985 to 1998, Pacific-Basin Finance J, Vol. 11, pp.239-265.

Lerong He. (2008). Do founders matter ? A study of executive compensation, governance structure and firm performance, Journal of Business Venturing, no 23 (3), pp. 257-279.

Jiraporn, P., Jiraporn N Boeprasert A and Chang, K. (2014). Does corporate social responsibility (CSR) improve credit ratings? Evidence from geographic identification, Financial Management, No 43(3), pp. 505-531.

Jiraporn P and Dalt P.J. (2004). Causes and consequences of audit shopping: an analysis of auditor opinions, Earnings management and auditor changes, WN Davidson.

Kumar J. (2004). Share holding Pattern and Firm Performance Finance, No 0409008, Econ WPA.

Kaufmann, Daniel A.K and Pablo Z.L. (1999). Aggregating Governance Indicators, World Bank Policy Research, Working Paper, No. 2195, Washington D.C

Kunz R.M and Angel J.J. (1996). Factors affecting the value of the stock voting right: Evidence from the Swiss equity market, Financial Management, pp. 7-20

Litov L.P. (2005). Corporate governance and financing policy: new evidence, working paper 
Mark K., Sattar A.M and William F.M. (2005). Does Corporate Governance Matter to Bondholders?, Journal of Financial and Quantitative Analysis, Vol. 40, issue 04, pp. 693-719.

Phillip T.L., Litov L.P and Landon M.M. (2015). Lead Independent Directors: Good Governance or Window Dressing?, Scholarly Papers, Arizona State University, University of Oklahoma - Michael F. Price College of Business and Florida State University, Department of Accounting.

Prommin P., Jumreornvong S and Jiraporn P. (2014). The effect of corporate governance on stock liquidity: The case of Thailand, International Review of Economics and Finance, Vol. 32, No 7, pp. 132-142.

Pablo de A.A and Eleuterio V.G. (2006). Corporate governance in banking: The role of Board of Directors, Document de Treball núm, Vol. 06/4

Sung W.J. (2003). Corporate governance and firm profitability: evidence from Korea before the economic crisis, Journal of Financial Economics, Vol. 68, issue 2, pp. 287-322

Stuart L.G and Laura T.S. (2003). Corporate Governance, Corporate Ownership, and the Role of Institutional Investors: A Global Perspective, Journal of Applied Finance, Vol. no 13, pp. 4-22.

Sun, Q, Tong, W and Tong, J. (2002). How does government ownership affect firm performance? Evidence from China's privatization experience, Journal of Business Finance and Accounting, no 29, pp.1-27.

The Macro Data Guide, Transparency International Social Sciences Conference in Kolkata-India. 1820 December 2015. 


\section{Appendices}

Table 1: Indicators of positions

\begin{tabular}{|c|c|c|c|c|}
\hline & Average & Médian & Maximum & Minimum \\
\hline$F D I-$ & & & & \\
\hline$G D P$ & 3.726222 & 2.003372 & 23.53736 & -0.469310 \\
\hline$V O A$ & -0.744149 & -0.768232 & 0.769107 & -1.960072 \\
\hline$S T A B$ & -0.634380 & -0.552506 & 0.788418 & -2.171064 \\
\hline$G O V$ & -0.147069 & -0.146406 & 1.345444 & -1.212487 \\
\hline$Q U A L$ & -0.254975 & -0.172288 & 1.215053 & -1.947827 \\
\hline STATE & -0.116055 & -0.106493 & 1.258530 & -1.156871 \\
\hline$C O R R$ & -0.252480 & -0.320450 & 1.471174 & -1.257209 \\
\hline$I N F$ & 26.69394 & 27.26709 & 29.28889 & 22.26934 \\
\hline $\mathrm{CH}$ & 73.19633 & 72.25140 & 111.1814 & 36.42012 \\
\hline$G D P$ & 4740.741 & 2247.805 & 22239.05 & 1203.193 \\
\hline
\end{tabular}


Table 2 : Dispersion Indicators

\begin{tabular}{|c|c|c|c|c|}
\hline & $\begin{array}{l}\text { Standard } \\
\text { deviation }\end{array}$ & Variance & $\begin{array}{c}\text { Coefficient of } \\
\text { Variation }\end{array}$ & Mean Error \\
\hline$F D I$ & 4.374718 & 19.13815 & 1.174036 & 0.3571942 \\
\hline$V O A$ & 0.6830973 & 0.466622 & -0.917958 & 0.0557747 \\
\hline$S T A B$ & 0.6328679 & 0.4005218 & -0.9976171 & 0.0516735 \\
\hline$G O V$ & 0.6407208 & 0.4105231 & -4.356602 & 0.0523146 \\
\hline$Q U A L$ & 0.7250448 & 0.52569 & -2.843587 & 0.0591997 \\
\hline STATE & 0.5490512 & 0.3014572 & -4.730944 & 0.0448298 \\
\hline CORR & 0.5931841 & 0.3518674 & -2.349429 & 0.0484333 \\
\hline$I N F$ & 11.86534 & 140.7864 & 0.7317869 & 0.9688012 \\
\hline $\mathrm{CH}$ & 17.98704 & 323.5337 & 0.2296295 & 1.473556 \\
\hline$G D P$ & 5391.987 & $2.91 \times 10^{7}$ & 1.137372 & 440.2539 \\
\hline
\end{tabular}


Table 3 : Form indicators

\begin{tabular}{|c|c|c|c|c|}
\hline & Skewness & Kurtosis & Jarque-Bera & Significance \\
\hline$F D I-$ & & & & \\
\hline$G D P$ & 1.799363 & 6.002603 & 137.2904 & 0.000000 \\
\hline$V O A$ & 0.388352 & 2.708219 & 4.302526 & 0.116337 \\
\hline$S T A B$ & -0.291610 & 2.524487 & 3.539106 & 0.170409 \\
\hline$G O V$ & 0.440394 & 2.735241 & 5.286786 & 0.071120 \\
\hline$Q U A L$ & -0.182855 & 2.827634 & 1.021586 & 0.600019 \\
\hline$S T A T E$ & 0.267919 & 2.848080 & 1.938767 & 0.379317 \\
\hline$C O R R$ & 0.900939 & 3.506524 & 21.89580 & 0.000018 \\
\hline$I N F$ & -0.656917 & 2.068415 & 16.21255 & 0.000302 \\
\hline $\mathrm{CH}$ & 0.145529 & 2.324609 & 3.380421 & 0.184481 \\
\hline$G D P$ & 2.179587 & 6.616568 & 200.5122 & 0.000000 \\
\hline
\end{tabular}

Table 4: The homogénéity tests

\begin{tabular}{|c|c|c|}
\hline & $\begin{array}{c}\text { Homogénéity of } \\
\text { constants }\end{array}$ & Homogénéity of coefficients \\
\hline FDI-GDP ${ }_{\text {it }}$ & $21.51(0,000)$ & $0.95(0.9754)$ \\
& & \\
\hline
\end{tabular}


Table 5: Estimation of FDI-GDP for the SEMC Zone

\begin{tabular}{|c|c|c|}
\hline Variables & Estimate Within & Estimate GLS \\
\hline$V O A$ & $-1.493164(0.477)$ & $-3.74525(0.059)$ \\
\hline \multirow[t]{2}{*}{$S T A B$} & & \\
\hline & $-1.560287(0.157)$ & $-0.9475856(0.394)$ \\
\hline \multirow[t]{2}{*}{$G O V$} & -5.092323(0.013) & \\
\hline & & $-5.225598(0.014)$ \\
\hline \multirow[t]{2}{*}{$Q U A L$} & & \\
\hline & $5.074164(0.063)$ & $9.126661(0.000)$ \\
\hline \multirow[t]{2}{*}{ STATE } & & \\
\hline & $3.259807(0.194)$ & $2.543866(0.348)$ \\
\hline \multirow[t]{2}{*}{$C O R R$} & & \\
\hline & $0.7269082(0.716)$ & $-1.772768(0.387)$ \\
\hline \multirow[t]{2}{*}{$I N F$} & & \\
\hline & $-0.2391452(0.004)$ & $-0.2211231(0.012)$ \\
\hline \multirow[t]{2}{*}{$L C H$} & & \\
\hline & $3.971918(0.096)$ & $3.084236(0.207)$ \\
\hline \multirow[t]{2}{*}{$L P I B$} & & \\
\hline & 1.612062(0.233) & $2.82394(0.049)$ \\
\hline
\end{tabular}


Table 6 : Hausman test

\begin{tabular}{|c|c|}
\hline & FDI-GDP $_{\text {it }}$ \\
\hline Stat-Hausman & $\chi^{2}(9)=261.04(0.000)$ \\
\hline
\end{tabular}

